\title{
FOOD AND FEEDING HABITS OF THE RED MULLET, MULLUS BARBATUS (ACTINOPTERYGII: PERCIFORMES: MULLIDAE), OFF THE NORTHERN TUNISIAN COAST (CENTRAL MEDITERRANEAN)
}

\author{
Mourad CHÉRIF ${ }^{1}$, Mohamed Mourad BEN AMOR $^{1}$, Salah SELMI ${ }^{1}$, Houcine GHARBI $^{1}$, \\ Hechmi MISSAOUI ${ }^{2}$, and Christian CAPAPÉ ${ }^{3 *}$ \\ ${ }^{1}$ Institut National des Sciences et Technologies de la Mer, La Goulette, Tunisia \\ ${ }^{2}$ Département des Ressources Animales, Halieutiques et des Technologies Agroalimentaires, \\ Institut National Agronomique de Tunisie, Tunis, Tunisia \\ ${ }^{3}$ Laboratoire d'Ichtyologie, Université Montpellier II, Sciences et Techniques du Languedoc, Montpellier, France
}

Chérif M., Ben Amor M.M., Selmi S., Gharbi H., Missaoui H., Capapé C. 2011. Food and feeding habits of the red mullet, Mullus barbatus (Actinopterygii: Perciformes: Mullidae), off the northern Tunisian coast (central Mediterranean). Acta Ichthyol. Piscat. 41 (2): 109-116.

Background. The red mullet, Mullus barbatus L., is abundantly captured and targeted throughout the year in Tunisian waters but not all aspects of its biology have been studied well. One of them - the feeding behaviour of this fish may be important for stock assessment, ecosystem modelling, and understanding mechanism and processes which structure and influence the fish assemblages. The aim of this paper is to describe the diet of specimens from the northern coast of Tunisia, to analyse seasonal variations in its composition and to delineate feeding intensity in relation to sex and size.

Materials and methods. Red mullet were sampled from different landing sites along the northern Tunisian coast and the Gulf of Tunis. Random samples were taken from both commercial and demersal trawlers from January to December 2005. A total of 472 specimens were examined following the commonly accepted procedures. The following parameters were analysed: vacuity index, percentage frequency of occurrence, percentage numerical abundance, percentage gravimetric composition, and index of relative importance. The trophic level for any consumer species was calculated, for total sample, but also in related to size, sex, and season.

Results. Mullus barbatus mainly fed on crustaceans and polychaetes. According to the classification of fishes in functional groups based on their TROPH red mullet is an omnivorous feeder, animal species being preferential preys. Basing on data assembled by Stergiou and Karpouzi for the Mediterranean ichthyofauna, the estimated trophic levels for the red mullet ranged between 2.79 and 3.57 units. Such within-species differences in trophic levels might reflect the combined effect of the following factors: area, year, length structure, and differential fishing pressure between years and/or areas, because fishing removes the largest individuals of a species, which generally have higher trophic levels.

Conclusion. The red mullet is not only omnivorous, but also opportunistic feeder with trophic level related to body size, season, geographic area and fishing pressure.

Keywords: Mullus barbatus, food composition, trophic level, Tunisia, central Mediterranean

\section{INTRODUCTION}

Of the three mullid species recorded to date in Tunisian waters, two are commonly recorded the red mullet, Mullus barbatus L., and the surmullet (or striped red mullet), M. surmuletus L. (see Bradaï et al. 2004). Both species are abundantly captured throughout the year; the mean production reached 4434.7 t between 2004 and 2008 (Anonymous 2008). The third species is the Por's goatfish, Upeneus pori Ben-Tuvia et Golani, 1989, one the Lessepsian migrant fish species, considered as successfully established in the eastern Mediterranean Sea (Golani et al. 2002). This latter species was firstly found in southern Tunisia by Ben Souissi et al. (2005), then, it migrated toward northern area, and was recorded in the brackish Lagoon of Bizerte by Azzouz et al. (2010). A second alien species was recorded only recently; it was identified as a specimen of the west African goatfish, Pseudupeneus prayensis (Cuvier, 1829), according to Azzouz et al. (2011).

Food and feeding habits of Mullus barbatus formed the object of several studies conducted from specimens

\footnotetext{
${ }^{*}$ Correspondence: Dr Christian Capapé, Laboratoire d'Ichtyologie, case 104, Université Montpellier II, Sciences et Techniques du Languedoc, 34095 Montpellier cedex 5 , France, phone: +33467544162, e-mail: capape@univ-montp2.fr
} 
caught off different Mediterranean areas (Wirszubski 1953, Jukic and Zupanovic 1967, Focardi et al. 1979, Caragitsou and Tsimenides 1982, Froglia 1988, Labropoulou et al. 1997, Badalamenti et al. 2000, Mahé et al. 2005, Layachi et al. 2007). With special regard to Tunisian marine waters, a single study was dealt three decades ago by Gharbi and Ktari (1979) for specimens caught in the Gulf of Tunis. The feeding behaviour of teleost species contributes to knowledge fish stock assessment and ecosystem modelling. Additionally, Kotrshall and Thomson (1986) noted that such study of feeding habits is necessary and useful to understand mechanism and processes which structure and influence fish assemblages. Thus, understanding of the food web structure of fishes may serve as a basis for the maintenance of trophic level balance, thereby preventing the fishing-induced trophic level decline (Stergiou and Karpouzi 2002) within an ecosystem context of fisheries management (see Browman et al. 2004). The aim of this paper is to describe the diet of Mullus barbatus northern coast of Tunisia, to analyse seasonal variations in its composition and to delineate feeding intensity in relation to sex and size, and also to try to assess regional differences between specimens from northern areas and the Gulf of Tunis.

\section{MATERIALS AND METHODS}

Red mullet, Mullus barbatus L., were sampled from different landing sites along northern Tunisian coast and the Gulf of Tunis (Fig. 1). This area is characterized by a small continental shelf with sandy and rocky bottoms, with depths not exceeding $200 \mathrm{~m}$; the mean water temperature reached $13^{\circ} \mathrm{C}$ in winter and $24^{\circ} \mathrm{C}$ in summer (Azouz 1973). Monthly samples were collected from January to December 2005 from both commercial and demersal trawlers. After landing, commercially caught specimens were preserved on ice, and transported to the laboratory, where they immediately processed. A total of 472 specimens were examined. Total length (TL) was recorded to the nearest $\mathrm{cm}$, and weighed for total mass to the nearest $\mathrm{g}$. Males and females were separately considered. The stomach contents of fresh specimens were removed, examined, and weighed. The preys were removed, sorted, and identified to the lowest possible taxonomic level using keys and fields (Riedl 1963, Perrier 1964, 1975, Fischer et al. 1987). The preys were counted and weighed to the nearest decigram.

In order to assess changes in diet versus total length, the sample was divided into four size classes: the first (TL $<10 \mathrm{~cm}, n=63)$, the second $(10<\mathrm{TL}<15 \mathrm{~cm}$, $n=153)$, the third $(15<\mathrm{TL}<20 \mathrm{~mm}, n=184)$ and the fourth (TL $>20 \mathrm{~cm}, n=72$ ). The four size classes were chosen as they approximate the age of the species, as determined from the Von Bertalanffy growth equation derived by Gharbi (unpublished*). Additionally, Gharbi (unpublished*) considered as adult all specimens larger than $13 \mathrm{~mm}$ TL.

To analyze the food and feeding habits of Mullus barbatus, we used some indices following Hureau (1970), Zander (1982), and Rosecchi and Nouaze (1987): vacuity index $(\mathrm{VI}=$ number of empty stomachs/total number of stomachs $\times 100)$, percentage frequency of occurrence

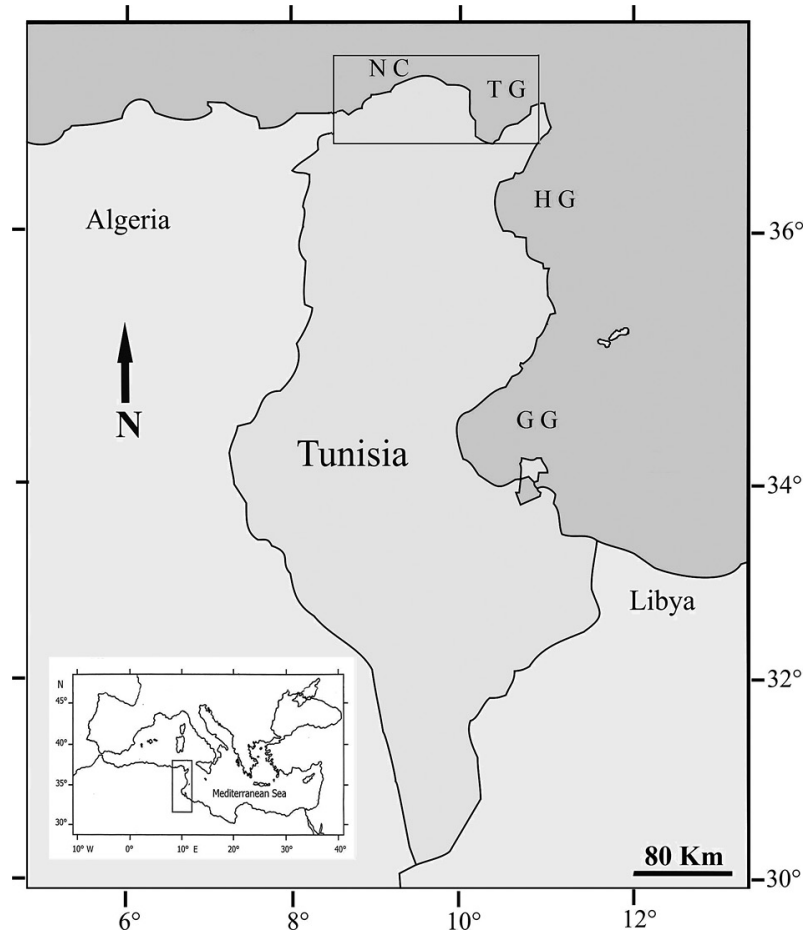

Fig. 1. Map of the Mediterranean (insert showing the Tunisian coast), with map of the Tunisian coast pointing out the sampling area, rectangular insert including northern coast (NC) and Gulf of Tunis (TG); GG: Gulf of Gabès; HG: Gulf of Hammamet

$(\% \mathrm{~F}=$ number of stomachs containing prey $\mathrm{i} /$ total number of full stomachs $\times 100$ ), percentage numerical abundance $(\% \mathrm{~N}=$ number of prey $\mathrm{i} /$ total number of prey $\times 100)$, and percentage gravimetric composition $(\% \mathrm{~W}=$ weight of prey $\mathrm{i} /$ total weight of all prey $\times 100)$. The index of relative importance (IRI) of Pinkas et al. (1971), as modified by Hacunda (1981): IRI $=\% \mathrm{~F} \times(\% \mathrm{~N}+\% \mathrm{~W})$. This index, that integrates the three previous percentages, allows an interpretation much more real for food by minimizing the skews caused by each one of these percentages.

In order to be able to determine the different categories of food, this food has been regrouped according to the classification proposed by Rosecchi and Nouaze (1987). The value of the index of every item is expressed in percentage of the sum of all indices ( $\sum$ IRI). Prey species were stored in decreasing order according to their percentage IRI contribution and then cumulative \%IRI was calculated. In this order, the \%IRI of first prey are gradually added until to obtain $50 \%$ or more, these items are main food; this calculation is pursued until has get $75 \%$ or more, these items are called secondary preys; the other items are accidentally

The diet composition data were also used for the estimation of the trophic level of the red mullet. The trophic level for any consumer species $i$ is (Pauly et al. 1998, Pauly and Christensen 2000, Pauly and Palomares 2000):

$$
\mathrm{TROPH}_{i}=1+\sum_{i=1}^{G} D C_{i j} \cdot \mathrm{TROPH}_{j}
$$


where $\mathrm{TROPH}_{j}$ is the fractional trophic level of prey $j$, $\mathrm{DC}_{i j}$ represents the fraction of $j$ in the diet of $i$ and $G$ is the total number of prey species.

The TROPH and (SE) standard errors of red mullet in the study area were calculated using TrophLab (Pauly et al. 2000); a standalone Microsoft Access routine for estimating trophic levels, downloadable from www.fishbase.org. The relationship between TROPH and the mid point of each length class considered here was quantified using the following equation (Cortés 1999):

$$
\mathrm{TROPH}_{L i}=\mathrm{TROPH}_{L \infty}\left(1-e^{-K L}{ }_{i}\right)
$$

where $\mathrm{TROPH}_{L \infty}$ is the asymptotic TROPH and $K$ is the rate at which $\mathrm{TROPH}_{L \infty}$ is approached (abbreviations as in Cortès (1999). Statistical differences $(P<0.05)$ in basic diet composition as a function of size and season were established by applying a c2 test (Sokal and Rohlf 1987).

\section{RESULTS}

Overall analysis of the diet. A total of 472 stomachs of red mullet were examined, the TL of specimens ranged between 8 and $21 \mathrm{~cm}$ for males, and between 8 and $24 \mathrm{~cm}$ for females. In all, 286 stomachs contained food or remains of food, with VI $=60.6 \%\left(c^{2}=22.63, P<0.05\right)$. Seven major systematic groups occurred in guts: polychaetes, crustaceans, molluscs, echinoderms, nematodes, teleosts, and algae (Table 1). It should be taken into consideration that, as a result of the degree of digestion of the prey, the determination to the level of species was often not possible.

The food composition of red mullet caught off northern Tunisian constituted mainly of crustaceans; polychaetes were secondary preys while molluscs, echinoderms, nematodes, teleosts, and algae were less frequent items in stomach contents.

The three diet indexes (Table 1) showed that crustaceans were preferentially consumed, and identified in higher abundance $(51.71 \%)$, weight $(47.46 \%)$, and occurrence $(131.1 \%)$. The crustaceans were mainly decapods (Pagurus sp.; $\mathrm{F}=29.74 \%$ ), amphipods (Gammarus gammarus; $\mathrm{F}=25.13 \%$ ), and euphausiids (Nyctiphanes sp.; $\mathrm{F}=22.09 \%)$. Less abundant crustaceans included mysids (Paramysis sp.; $\mathrm{F}=18.23 \%)$, isopods $(\mathrm{F}=21.34 \%)$, and cumaceans $(\mathrm{F}=14.57 \%)$. Polychaetes (Nereis caudata) are also consumed in fairly large proportions $(\mathrm{F}=59.31 \%)$.

Mullus barbatus fed occasionally on molluscs species identified in relative abundance $11.96 \%$ and weight $13.68 \%$. Among them, mesogastropoda (Turitella sp.; F $=11.05 \%$ ) and bullomopha (Philine sp.; $\mathrm{F}=7.73 \%$ ) were the most recorded. Additionally, echinoderms were present in fairly large proportions in the stomach contents by mass and number $(\% \mathrm{~W}=7.18 ; \% \mathrm{~N}=7.31$ respectively $)$. Other taxa found in the stomach contents, but of lesser importance, were nematodes, teleosts, and algal remains (Table 1).

Diet composition of Mullus barbatus from the northern Tunisian coast

\begin{tabular}{|c|c|c|c|c|c|c|c|}
\hline \multicolumn{4}{|c|}{ Prey item taxonomic identity } & \multirow{2}{*}{$\begin{array}{c}\% \mathrm{~F} \\
59.31\end{array}$} & \multirow{2}{*}{$\begin{array}{c}\% \mathrm{~N} \\
18.28\end{array}$} & \multirow{2}{*}{$\begin{array}{c}\% \mathrm{~W} \\
23.52\end{array}$} & \multirow{2}{*}{$\begin{array}{l}\text { \%IRI } \\
14.72\end{array}$} \\
\hline Polychaeta & Phyllodocida & Nereidae & Nereis caudata & & & & \\
\hline \multirow{6}{*}{ Crustacea } & Decapoda & Paguridae & Pagurus sp. & 29.74 & 10.42 & 14.65 & 23.41 \\
\hline & Amphipoda & Gammaridae & Gammarus gammarus & 25.13 & 9.31 & 12.74 & 17.17 \\
\hline & Euphausiacea & Euphausiidae & Nyctiphane sp. & 22.09 & 8.21 & 8.27 & 14.34 \\
\hline & Mysidacea & Mysidae & Paramysis sp. & 18.23 & 7.12 & 4.12 & 7.76 \\
\hline & Isopoda & \multicolumn{2}{|c|}{ Unidentified remains } & 21.34 & 9.06 & 5.52 & 9.25 \\
\hline & Cumacea & \multicolumn{2}{|c|}{ Unidentified remains } & 14.57 & 7.59 & 2.16 & 5.54 \\
\hline \multicolumn{4}{|l|}{ Total Crustacea } & 131.1 & 51.71 & 47.46 & 77.47 \\
\hline \multirow{4}{*}{ Mollusca } & \multicolumn{2}{|c|}{ Mesogastropoda Turritellidae } & Turitella sp. & 11.05 & 5.11 & 3.17 & 2.44 \\
\hline & Bullomopha & Philinidae & Philine sp. & 7.73 & 3.32 & 2.35 & 1.38 \\
\hline & Pectinoidea & Pectinidae & Unidentified remains & 5.35 & 1.31 & 2.52 & 0.66 \\
\hline & Nuculoidea & Nuculanidae & Nucula pella & 6.98 & 2.22 & 5.64 & 0.27 \\
\hline \multicolumn{4}{|l|}{ Total Mollusca } & 31.11 & 11.96 & 13.68 & 4.75 \\
\hline \multirow{3}{*}{ Echinodermata } & Ophiuroidea & Amphiuridae & Unidentified remains & 7.48 & 2.22 & 3.49 & 0.65 \\
\hline & Echinoidea & Regularia & Unidentified remains & 8.91 & 2.97 & 2.42 & 0.92 \\
\hline & Asteroidea & Unidentified $\mathrm{r}$ & mains & 6.13 & 2.12 & 1.27 & 0.37 \\
\hline \multicolumn{4}{|c|}{ Total Echinodermata } & 22.52 & 7.31 & 7.18 & 1.94 \\
\hline Teleostei & \multicolumn{3}{|c|}{ Unidentified remains } & 9.45 & 3.28 & 2.35 & 0.32 \\
\hline Nematoda & \multicolumn{3}{|c|}{ Unidentified remains } & 6.72 & 2.43 & 1.71 & 0.18 \\
\hline Algae & \multicolumn{3}{|c|}{ Unidentified remains } & 4.71 & 1.01 & 1.23 & 0.15 \\
\hline \multicolumn{4}{|c|}{ Total unidentified remains } & 12.54 & 4.02 & 2.87 & 0.47 \\
\hline
\end{tabular}

$\% \mathrm{~N}=$ percentage by number; $\% \mathrm{~W}=$ percentage by weight; $\% \mathrm{~F}=$ percentage by occurrence; $\% \mathrm{IRI}=$ index of relative importance. 
Analysis based on the feeding index (\%IRI) showed that crustaceans were mostly ingested by Mullus barbatus, decapods ( $\% \mathrm{IRI}=23.41)$, amphipods $(\% \mathrm{IRI}=17.17)$, and euphausiasids $(\% \mathrm{IRI}=14.34)$, (see Table 1$)$. The TROPH of M. barbatus from northern Tunisian coast was $3.39(\mathrm{SE}=0.45)$ indicating that the species could be considered an omnivore, however animal preys were mainly found in stomach contents $(2.9<\mathrm{TROPH}>3.7)$.

Diet related to sex. Of the 168 male stomach contents examined (TL ranged between 8 and $21 \mathrm{~cm}$ ), 98 were empty (VI $=20.76 \%$ ), whilst of the 304 female stomach contents examined (TL ranged between 8 and $24 \mathrm{~cm}$ ), 188 were empty $(\mathrm{VI}=39.83 \%)$ : VI significantly differed between males and females $\left(c^{2}=11.02, P<0.05\right)$. The $\%$ IRI index indicates that the main prey group was crustaceans for both males and females, \%IRI $=78.53$ and $\%$ IRI $=81.47$, respectively (Table 2$)$. The trophic level did not change with sex, it was $3.35(\mathrm{SE}=0.41)$ for males and $3.38(\mathrm{SE}=0.43)$ for females $\left(\mathrm{c}^{2}=0.67, P>0.05 ; \mathrm{df}=1\right)$.

Diet related to size. The diet of Mullus barbatus showed changes related to size (Table 3). Teleosts were found only

Table 2

Diet composition for males $(n=168)$ and females $(n=304)$ of Mullus barbatus from the northern Tunisian coast:

\begin{tabular}{lrc}
\hline \multirow{2}{*}{ Prey item } & Male & Female \\
\cline { 2 - 3 } & \%IRI & \%IRI \\
\hline Polycheata & 13.09 & 12.64 \\
Crustacea & 78.53 & 81.47 \\
Mollusca & 4.86 & 3.15 \\
Echinodermata & 1.42 & 0.94 \\
Nematoda & 0.13 & 0.18 \\
Osteichthyes & 0.08 & 0.12 \\
Algae & 0.11 & 0.27 \\
Unidentified items & 1.78 & 1.23 \\
\hline
\end{tabular}

$\% \mathrm{IRI}=$ index of relative importance.

Table 3

Diet composition for each size-class of Mullus barbatus from the northern Tunisian coast

\begin{tabular}{lcccc}
\hline \multirow{2}{*}{ Prey item } & \multicolumn{5}{c}{ Fish length class $(\% \mathrm{IRI})[\mathrm{cm}]$} \\
\cline { 2 - 5 } & $\begin{array}{c}<10 \\
(n=63)\end{array}$ & $\begin{array}{c}10-15 \\
n=153)\end{array}$ & $\begin{array}{c}15-20 \\
n=184)\end{array}$ & $\begin{array}{c}>20 \\
n=72)\end{array}$ \\
\hline Polychetea & 12.97 & 12.7 & 14.02 & 14.24 \\
Crustacea & 77.68 & 78.22 & 80.14 & 80.34 \\
Mollusca & 3.43 & 2.71 & 2.35 & 2.03 \\
Echinodermata & 2.72 & 2.43 & 1.16 & 1.17 \\
Nematoda & 1.35 & 1.33 & 0.67 & 0.32 \\
Osteichthyes & 0.11 & 0.6 & & \\
Algae & & 0.64 & 0.47 & 0.78 \\
Unidentified items & 1.74 & 1.37 & 1.19 & 1.12 \\
\hline
\end{tabular}

$\%$ IRI $=$ index of relative importance. in the smallest size class of specimens (TL $<10 \mathrm{~cm})$ and algae only in the larger classes. Additionally, \%IRI index analysis applied to all size-classes showed that crustaceans and polychaetes constituted the main prey category. Molluscs were the secondary prey; remaining prey such as echinoderms and nematodes were of minor importance and maybe accidental food. The percentage of the index of relative importance (\% IRI) of polychaetes, crustaceans, and molluscs varied significantly between size categories $\left(\mathrm{c}^{2}=85.42 ; P<0.05 ; \mathrm{df}=3\right)$.

The importance of crustaceans and polychaetes increased with size, concomitantly the importance of molluscs and echinoderms decreased (Table 4). However, remains of preys such as nematodes and algae were not significantly different among the size classes. The trophic level of Mullus barbatus increased with size (Fig. 2). The relation between TROPH and size (TL, cm) was asymptotic:

$$
\mathrm{TROPH}_{L i}=3.44\left(1-e^{-0.43 L i}\right)
$$

Seasonal variation in the diet composition. The analysis of stomach contents showed that VI was affected by seasonal changes, higher in spring and summer, reaching $61.5 \%$ and $67.3 \%$, respectively, and decreased from $46.9 \%$ to $40.4 \%$ during autumn and winter, respectively. These percentages were significantly different within the year $\left(\mathrm{c}^{2}=17.51, P>0.05 ; \mathrm{df}=3\right)$.

Table 4

Seasonal changes in Mullus barbatus

from the Northern Tunisian coast diet based on the index of relative importance (\%IRI) values of major prey groups

\begin{tabular}{lcccc}
\hline \multirow{2}{*}{ Prey item } & \multicolumn{4}{c}{ Index of relative importance (\%IRI) } \\
\cline { 2 - 5 } & $\begin{array}{c}\text { Winter } \\
(n=115)\end{array}$ & $\begin{array}{c}\text { Spring } \\
(n=109)\end{array}$ & $\begin{array}{c}\text { Summer } \\
(n=107)\end{array}$ & $\begin{array}{c}\text { Autumn } \\
(n=131)\end{array}$ \\
\hline Polychaeta & 14.23 & 13.4 & 13.46 & 14.67 \\
Crustacea & 78.56 & 78.9 & 79.37 & 77.82 \\
Mollusca & 3.11 & 3.41 & 3.64 & 4.02 \\
Echinodermata & 1.1 & 0.67 & 0.91 & 0.73 \\
Nematoda & 0.1 & 0.1 & 0.13 & 0.21 \\
Osteichthyes & & & 0.12 & 0.1 \\
Algae & 0.19 & 0.1 & & 0.08 \\
Unidentified items & 1.12 & 1.2 & 1.45 & 1.31 \\
\hline
\end{tabular}

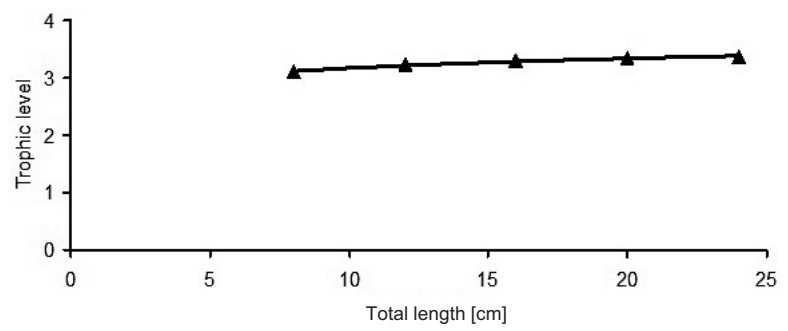

Fig. 2. Relation between trophic level (TROPH) and total length (TL) of Mullus barbatus off the northern Tunisian coast 
Crustaceans and polychaetes were the dominant prey groups throughout the year, especially in autumn and winter. Crustaceans occurred in stomach contents throughout the year, the maximum \%IRI $(=79.37)$ was recorded in summer. Polychaetes were also present in guts during all seasons, while teleosts were only found in summer and autumn (Table 4).

Seasonal significant differences weren't found for remaining prey group $\left(\mathrm{c}^{2}=1.17, P>0.05\right)$. The TROPH of red mullet did show significant changes with season; 3.41 in spring, 3.40 in summer, 3.36 in autumn, and 3.38 in winter $\left(\mathrm{c}^{2}=7.67 ; P<0.05 ; \mathrm{df}=3\right)$.

\section{DISCUSSION}

The food composition of red mullet, Mullus barbatus L., caught off northern Tunisian was mainly constituted by crustaceans species, polychaetes were secondary preys while molluscs, echinoderms, nematodes*, osteichthyans, and algae were of minor importance in stomach contents. This diet composition was partially in agreement with previous studies carried out in other marine areas. In the Tunisian coast, Gharbi and Ktari (1979) noted that red mullet caught in the Gulf of Tunis fed on crustaceans (amphipods, decapods, and isopods) and less intensively on polychaetes and molluscs. Layachi et al. (2007) reported that specimens from the Mediterranean coast of Morocco consumed crustaceans amphipods, polychaetes, and bivalves while decapods, isopods and nematodes were secondary preys. Studies conducted in western Greek Sea showed that the diet of Mullus barbatus consisted in crustaceans, polychaetes and bivalves (Caragitsou and Tsimenidis 1982, Papaconstantinou and Caragitsou 1987). By contrast, other studies conducted in the same area pointed out that the species mainly fed mainly on polychaetes, molluses, echinoderms, and a bit less on teleosts (Vassilopoulou and Papaconstantinou 1993, Labropoulou and Elefheriou 1997, Machias and Labropoulou 2002), while similar pattern was reported in specimens from the eastern Mediterranean by Wirszubski (1953). These changes in diet are not very important; they could be the results of sampling and/or biological environment. The large spectrum of both prey groups and of prey items species recorded in guts indicated that red mullet could be considered specialist an opportunist feeders. The morphological characteristics and the foraging behaviour of Mullus barbatus account for both prey type selection and the feeding patterns observed (Labropoulou et al 1997, Machias and Labropoulou 2002).

The high levels of vacuity index recorded in spring and summer suggest that red mullet from the Tunisian coast eat less during these seasons. Such phenomenon is probably due to the fact that breeding period occurred in spring and early summer, and during this period gonads increased in size and mass and completely filled the visceral cavity (Cherif et al. 2007). Similar patterns were observed in other Mediterranean regions for Mullus barbatus from Morocco (Layachi et al. 2007).

Changes in food composition with fish size are well known among fishes (Nikolsky 1963). In the presently reported study, the mode of feeding patterns for Mullus barbatus shows a significant difference between adult and juveniles, these latter having a total length less than $13 \mathrm{~cm}$ following Gharbi (unpublished ${ }^{* *}$ ). The importance of crustaceans and polychaetes increased with size, while concomitantly the importance of molluscs and echinoderms decreased. This may be the result of the fact that as fish grow their relative success rates increase due to ontogenetic changes in sensory and swimming capacities (Juanes and Conover 1994) as well as in mouth morphology, so they become experimented and active feeders, with larger preys are included in the diet (Negzaoui-Garali et al. 2008). The present results are in agreement with those reported by (Machias and Labropoulou 2002) for Mullus barbatus off the western coast of Greece, as they mentioned that the composition of the prey consumed varied considerably with fish size. In particular, younger individuals exhibited the most restricted distribution and appeared to have a broader trophic niche than the larger size classes that occurred over a wider depth range. However, Vassilopoulou and Papaconstantinou 1993 noted that the prey species composition in the stomachs of red mullet was influenced by area of capture rather than fish length. Taking this data into account, it could be concluded that red mullet diet also changed with the abundance of different preys occurring in the biological environment.

The feeding intensity of Mullus barbatus showed some seasonal changes. The main diet components of male and female red mullet were crustaceans and polychaetes throughout the year in agreement with observations carried out on red mullet from the Gulf of Lions (northwestern Mediterranean) by Bautista-Vega et al. (2008). Diet changed are linked to prey availability in relation with the dynamics of the water masses in the region, similar patterns were reported for Moroccan coast (Layachi et al. 2007), the Gulf of Tunis (Gharbi and Ktari 1979), Spanish waters (Aguirre and Sánchez 2005), and western Greece Sea (Vassilopoulou and Papaconstantinou 1993). The diet of Mullus barbatus from the northern Tunisian coast showed the importance of decapods (Pagurus sp.) and amphipods (Gammarus gammarus) throughout the year, in agreement with previous feeding studies that pointed out the occurrence of same preys in stomachs of other demersal teleost species, such as Mullus surmuletus and Labrus merula, indicating the abundance of such preys off the northern Tunisian coast (Gharbi and Ktari 1979, Ben Slama et al. 2007).

Our results indicate that Mullus barbatus mainly fed on small crustaceans and polychaetes. Conversely, large crustaceans, such as shrimps were not found in guts probably because $M$. barbatus feeds on small benthic invertebrates, inhabiting sandy and/or muddy bottoms, and detected by chemoreceptor barbels on the chin (Hureau 1986). N'Da (unpublished ${ }^{* * *}$ ) reported that mullet collected from the Bay of Biscay fed on small preys such as cumaceans, amphipods, copepods, the largest items were gobiids having between 10 and $15 \mathrm{~mm}$ total length. N'Da (unpublished $* * *)$ noted that mullet present a relatively small 
mouth and small teeth, it is rather specialized for suction captures of small preys which live in or on the substrate.

According to the classification of fishes in functional groups based on their TROPH (Stergiou and Karpouzi 2002), red mullet is an omnivorous feeder, however animal species were more consumed than algae, for instance. Similar feeding habits were reported for red mullet elsewhere such as in Mediterranean area. Basing on data assembled by Stergiou and Karpouzi (2002) for the Mediterranean ichthyofauna, the estimated trophic levels for the red mullet ranged between 2.79 and 3.57 units. The changes of trophic levels recorded in $M$. barbatus might reflect the combined effect of the following factors: area, year, length structure, and differential fishing pressure between years and/or areas, because fishing removes the largest individuals of a species, which generally have higher trophic levels (Stergiou and Karpouzi 2002, Negzaoui-Garali et al. 2008). The differences could also reflect the impact of other factors such as different methodology during investigations.

In conclusion, the results of the presently reported study and data from other areas show that red mullet is not only omnivorous, but also opportunistic feeder with trophic level related to body size, season, geographic area and fishing pressure which cannot be also excluded. Since 1980, the general use of shrimp boats with non selective nets, almost involved the destruction of benthic resources throughout the Tunisian marine waters, playing a negative role on local biodiversity, and considerably reducing prey species availability (Gharbi et al 2004). The study of natural diets of fish species is very useful approach for understanding aspect of the species biology and ecology, towards a more sustainable management of their stocks and the development of conservation measures (La Mesa et al. 2007, Kitsos et al. 2008). A competition pressure for food cannot be totally excluded in the future between these closely related species, as it is the case for other Mediterranean areas, where M. barbatus and M. surmuletus were progessively replaced by other invasive species (Golani 1994). So a recent paper on diet composition of M. barbatus is needed to explain a probable interspecific competition between mullid species in the area. Food seems to be sufficiently available, at present, for two mullids species, this explained why we have cited both sympatric species. To date, it seems impossible to state if the biological environment will be qualitatively and quantitatively sufficient for other related which feed on same preys species.

\section{REFERENCES}

Aguirre H., Sánchez P. 2005. Feeding resource partitioning between Mullus barbatus and M. surmuletus in the Catalan Sea (northwestern Mediterranean). Ciencias Marinas 31 (2): 429-439.

Anonymous 2008. Annuaires des statistiques des produits de la pêche en Tunisie, Direction Générale à la Pêche et à l'Aquaculture (DGPA). Ministère de l'Agriculture et des Ressources Hydrauliques (M.A.R.H).
Azouz A. 1973. Les fonds chalutables de la région Nord de la Tunisie. 1: Cadre physique des côtes nord de la Tunisie. Bulletin de l'Institut national scientifique et technique d'océanographie et de pêche de Salammbô 2 (4): 473-563.

Azzouz K., Mansour S., Boumaïza M., Capapé C. 2010. Occurrence of the Por's goatfish Upeneus pori (Osteichthyes: Mullidae) in the Lagoon of Bizerte (northern Tunisia, central Mediterranean). Annales series Historia naturalis 19 (1): 29-32.

Azzouz K., Diatta Y., Mansour S., Boumaïza M, Ben Amor M.M., Capapé C. 2011. First record of the west African goatfish Pseudupeneus prayensis (Osteichthyes: Mullidae) off the Tunisian coast (central Mediterranean). Acta Ichthyologica et Piscatoria 41 (2): 133-136. DOI: 10.3750/AIP2011.41.2.10.

Badalamenti F., Pinnegar J.K., Polunin N.V.C., D'Anna G. 2000. Estimates of trophic level in the red mullet Mullus barbatus: Comparison between gut-contents and stable-isotope data. Pp. 19-21. In: Briand F. (ed.) Fishing down the Mediterranean food webs? CIESM Workshop Series, Vol. 12.

Bautista-Vega A., Letourneur Y., Harmelin-Vivien M., Salen-Picard. 2008. Difference in diet and size-related trophic level in two sympatric fish species, the red mullets Mullus barbatus and Mullus surmuletus, in the Gulf of Lions (northwest Mediterranean Sea). Journal of Fish Biology 73 (10): 2402-2420. DOI: 10.1111/j.1095-8649.2008.02093.x.

Ben Souissi J., Mejri H., Zaouali J., Capapé C. 2005. On the occurrence of the Por's goatfish, Upenueus pori (Mullidae) in southern Tunisia (central Mediterranean). Cybium 29 (4): 410-412.

Ben Slama S., Menif D., Ben Hassine O.K. 2007. Regime alimentaire de Labrus merula (Labridae) des côtes nord de Tunisie. Cybium 31 (2): 175-180.

Bradaï M.N., Quignard J.-P., Bouain A., Jarboui O., Ouannes-Ghorbel A., Ben Abdallah L., Zaouali J., Ben Salem S. 2004. Ichtyofaune autochtone et exotique des côtes tunisiennes: Recensement et biogéographie. Cybium 28 (4): 315-328.

Browman H.I., Cury P.M., Hilborn R., Jennings S., Lotze H.K., Mace P.M., Murawski S., Pauly D., Sissenwine M., Stergiou K.I., Zeller D. 2004. Perspectives on ecosystembased approaches to the management of marine resources. Marine Ecology Progress Series 274: 269-303.

Caragitsou E., Tsimenidis N. 1982. Seasonal changes of food spectrum and daytime rhythm of feeding of the red mullet (Mullus barbatus) in the Thracian Sea. Thalassographica 5: 105-115.

Cherif M., Zarrad R., Gharbi H., Missaoui H., Jarboui O. 2007. Some biological parameters of the red mullet, Mullus barbatus L., 1758, from the Gulf of Tunis. Acta Adriatica 48 (2): 131-144.

Cortés E. 1999. Standardized diet compositions and trophic levels of sharks. ICES Journal of Marine Science 56 (5): 707-717.

Fischer W., Bauchot M.L., Schneider M. 1987. Fiches FAO d'Identification des Espèces pour les Besoins de la Pêche (révision 1). Méditerranée et Mer Noire. Zone de pêche 37. Vol. I \& II. FAO, Rome. 
Focardi S., Falciai L., Gambi C., Spadini V. 1979. Alimentazione di Mullus barbatus L. nel Mar Tirreno. [Feeding of Mullus barbatus L. from the the Tirrenean Sea.] XI Congresso della Societá Italiana di Biologia Marina, Orbetello. Atti della Societá Toscana di Scienze Naturale, Memoria 86 (suppl.): 392-395.

Froglia C. 1988. Food preferences of juvenile red mullet Mullus barbatus in Western Adriatic nursery ground (Osteichthyes: Mullidae). Rapports et Procès-Verbaux du Comité international pour l'exploration scientifique de la mer Méditerranée 31: 263.

Gharbi H., Ktari M.H. 1979. Régime alimentaire des rougets (Mullus barbatus Linnaeus, 1758 et Mullus sunnuletus Linnaeus, 1758) du golfe de Tunis. Bulletin de l'Institut national scientifique et technique d'océanographie et de pêche de Salammbô 6 (1-4): 41-52.

Gharbi H., Ben Meriem S., Bedoui R., El Abed A. 2004. Les pêcheries tunisiennes du rouget de vase (Mullus barbatus Linnaeus, 1758): évaluation des stocks et aménagement des pêcheries. Marine Life 14 ( 1-2): 49-57.

Golani D. 1994. Niche separation between colonizing and indigenous goatfish (Mullidae) along the Mediterrranean coast of Israel. Journal of Fish Biology 45 (3): 503-513. DOI: 10.1111/j.1095-8649.1994.tb01332.x.

Golani D., Orsi-Relini L., Massuti E., Quignard, J.-P. 2002. CIESM Atlas of exotic species in the Mediterranean. Vol. 1. In: Briand F. (ed.) Fishes. CIESM Publications, Monaco.

Hacunda J.S. 1981. Trophic relationships among demersal fishes in coastal area of the Golf of Maine. Fisheries Bulletin 79 (4): 775-788.

Hureau J.C. 1970. Biologie comparée de quelques poissons antarctiques (Notothenidae). Bulletin de l'Institut océanographique de Monaco 68 (1391): 1-244.

Juanes F., Conover D.O. 1994. Piscivory and prey size selection in young-of-the-year bluefish: Predator preference or size-dependent capture success? Marine Ecology Progress Series 114: 59- 69 .

Jukic S., Zupanovic S. 1967. Relations entre la temperature et l'intensite de l'alimentation chez Mullus barbatus (L.) et Pagellus erythrinus (L.) dans la baie de Kastela. Proceeding of the General Fisheries Commission for the Mediterranean 8 (Technical Paper 17): 173-177.

Kitsos M.-S., Tzomos Th., Anagnostopoulou L., Koukouras A. 2008. Diet composition of the seahorses, Hippocampus guttulatus Cuvier, 1829 and Hippocampus hippocampus (L., 1758) (Teleostei, Syngathidae) in the Aegean Sea. Journal of Fish Biology 72 (6): 1259-1267. DOI: 10.1111/j.1095-8649.2007.01789.x.

Kotrshall K., Thompson D.A. 1986. Feeding patterns in eastern tropical Pacific blennioid fishes (Teleostei: Triptrygiidae, Labrisomidae, Chaenopsidae, Blennidae). Oecologia 70 (3): 367-378.

La Mesa G., La Mesa M., Tomassetti P. 2007. Feeding habits of the Madeira rockfish, Scorpaena maderensis, from central Mediterranean Sea. Marine Biology 150 (6): 1313-1320. DOI: 10.1007/s00227-006-0414-1.

Labropoulou M., Eleftheriou A. 1997. The foraging ecology of two pairs of congeneric demersal fish species: importance of morphological characteristics in prey selection. Journal of Fish Biology 50 (2): 324-340. DOI: 10.1111/j.1095-8649.1997.tb01361.x.
Labropoulou M., Machias A., Tsimenides N., Eleftheriou A. 1997. Feeding habits and ontogenetic shift of the striped red mullet, Mullus surmuletus Linnaeus, 1758. Fisheries Research 31 (3): 257-267.

Layachi M., Melhaoui M., Ramdani M., Srour A. 2007. Etude préliminaire du régime alimentaire du Rouget-barbet (Mullus barbatus L.) de la côte nord-est méditerranéenne du Maroc (Nador) au cours de l'année 2001 (Poissons, Mullidae). Bulletin de l'Institut Scientifique de Rabat, section des Sciences de la Vie 29: 35-41.

Machias A., Labropoulou M. 2002. Intra-specific variation in resource use by red mullet, Mullus barbatus. Estuarine, Coastal and Shelf Science 55 (4): 565-578. DOI: 10.1006/ecss.2001.0924.

Mahé K., Destombes A., Coppin F., Koubbi P., Vaz S., Le Roy D., Carpentier A. 2005. Le rouget barbet de roche Mullus surmuletus (L. 1758) en Manche orientale et mer du Nord. Rapport de Contrat IFREMER/CRPMEM, Nord-Pasde-Calais.

Negzaoui-Garali N., Ben Salem M., Capapé C. 2008. Feeding habits of the black anglerfish, Lophius budegassa (Osteichthyes: Lophiidae) off the Tunisian coast (central Mediterranean). Cahiers de Biologie Marine 49 (2): 113-122.

Nikolsky G.V. 1963. The ecology of fishes. Academic Press, London and New York.

Papaconstantinou C., Caragitsou E. 1987. Prokatarktikī meletī tōn trofikōn scheseōn tīs koutsomouras Mullus barbatus L. se treis thalassies perioches kata mīkos tōn dytikōn aktōn tīs Elladas. [Preliminary study on the trophic relation of red mullet (Mullus barbatus) in three areas along the western coasts of Greece.] Pp. 577- 583. In: B' Panellinnio Symposio Ōkeanografias kai alieias [Proceding of the 2nd Panhellenic Symposium on Oceanographic Fisheries.] 14-17 May 1990, National Centre for Marine Research, Athens. [In Greek.]

Pauly D., Christensen V. 2000. Trophic levels of fishes. In: Froese R., Pauly D. (eds.) Fishbase 2000: Concepts, design and data sources. ICLARM, Manila, Philippines.

Pauly D., Palomares M.L. 2000. Approaches for dealing with three sources of bias when studying the fishing down marine food web phenomenon. Pp. 61-66. In: Briand F. (ed.) Fishing down the Mediterranean food webs? CIESM Workshop Series 12.

Pauly D., Trites A.W., Capuli E., Christensen V. 1998. Diet composition and trophic levels of marine mammals. ICES Journal of Marine Science 55: 467-481.

Pauly D., Froese R., Sa-a P., Palomares M.L., Christensen V., Rius J. 2000. TrophLab Manual. ICLARM, Manila, Philippines.

Perrier R. 1964. La faune de la France illustrée. 1B. Vers et némathelminthes. Delagrave, Paris.

Perrier R. 1975. La faune de la France illustrée. II. Arachnides et crustacés. Delagrave, Paris.

Pinkas L., Oliphant M.S., Iverson I.L.K. 1971. Food habits of albacore, blue-fin tuna, and bonito in California waters. California Fish and Game 152: 1-105.

Riedl R. 1963. Fauna and flora der Adria. Paul Parey, Hamburg 
Rosecchi E., Nouaze Y. 1987. Comparaison de cinq indices alimentaires utilisés dans l'analyse des contenus stomacaux. Revue de l'Institut des Pêches maritimes 49 (3-4): 111-123.

Sokal R.R., Rohlf F.J. 1987. Biostatistics. W.H. Freeman, New York.

Stergiou K.I., Karpouzi V.S. 2002. Feeding habits and trophic levels of Mediterranean fish. Reviews in Fish Biology and Fisheries 11 (3): 217-254. DOI: 10.1023/A:1020556722822.

Vassilopoulou V., Papaconstantinou C. 1993. Feeding habits of red mullet (Mullus barbatus) in a gulf in western Greece. Fisheries Research 16 (1): 69-83.

DOI: 10.1016/0165-7836(93)90110-S.
Wirszubski A. 1953. On the biology and biotope of the red mullet (Mullus barbatus L.). Ministry of agriculture, Ministry of Fisheries Israel. Bulletin 7: 19.

Zander C.D. 1982. Feeding ecology of littoral gobiid and blennioid fish of the Banyuls area (Mediterranean Sea). Item Main Food and trophic dimension of niche and ecotope. Vie et Milieu 32 (1): 1-10.

Received: 18 November 2010

Accepted: 16 April 2011

Published electronically: 30 June 2011 